\title{
Boom and Bust of Foreign Assets under Integrated Banking Systems
}

\author{
Maiko Koga \\ Bank of Japan, Tokyo, Japan \\ Koichi Yoshino \\ Bank of Japan, Osaka, Japan
}

\begin{abstract}
We examine whether highly integrated banking systems across borders escalated the boom and the bust of foreign assets owned by banks before and after the global financial crisis. As the financial shock dramatically affected the banking system across the globe, considering only the primary and secondary exposures to the initial shock is inadequate to capture the effect of bank linkages. Using a new specification that accommodates the situation of interconnected banking systems, we explore an overall similarity of lending structures generating the shock amplification. We also investigate whether this effect is shown differently between the boom and the bust periods and between investing areas. To prevent the spread of financial shock, our findings suggest that banks should hold a unique funding structure.
\end{abstract}

\footnotetext{
* Corresponding Author: Maiko Koga; Research and Statistics Department, Bank of Japan, 2-1-1 Nihonbashi Hongokucho Chuo-ku, Tokyo 103-8660, Japan; Tel: +81 332791111, E-mail: maiko.koga.8@gmail.com.

Co-author: Koichi Yoshino; Osaka Branch, Bank of Japan, 2-1-45 Nakanoshima, Kita-ku, Osaka 530-0005, Japan; Tel: +81 332791111, E-mail: koichi.yoshino@gmail.com.

Acknowledgements: We would like to thank seminar participants at Osaka University for their helpful comments on an earlier version of this paper. We also thank an anonymous referee for valuable comments and suggestions. The views expressed herein are those of the authors and do not reflect those of the Bank of Japan, which does not accept any responsibility for the contents and opinions expressed in this paper.
} 
JEL Classifications: G15, G21, F32, F34

Keywords: International Banks, Financial Crisis, Cross-border Lending

\section{Introduction}

As the banking industry has been increasingly globalized, financial integration through banking sectors has advanced across the globe. ${ }^{1}$ Such integrated banking systems have been seen as an intermediary to propagate a financial shock across borders in addition to other channels like trade and financial market transaction.

Contagion risk through a banking system has been explored in many studies. One typical approach is identification of external (push) and internal (pull) determinants of lending flows (Buch 2000, Goldberg 2002). Peek and Rosengren (1997) found that the financial shock of Japanese banks resulted in a decrease in lending in the United States. De Haas and van Lelyveld (2009) examined the multinational banks' support for their subsidiaries to expand their lending. Kaminsky and Reinhart (2000) and Van Rijckeghem and Weder (2003) showed that the indirect linkage is also effective in spreading financial shocks across borders. They explored the mechanism in which the countries face the withdrawal of funds when they have a common lender, even though they are not directly exposed to it.

More recently, the global financial crisis renewed interest to the role of bank linkages. IMF (2009) found that bank flow was a stronger channel for spreading shocks between advanced and emerging countries than other linkages such as trade, direct investment, and financial portfolio. Cetorelli and Goldberg (2011) established that adverse liquidity shocks on advanced countries spread through banks in the global financial crisis. More recently, Aiyar and Jain-Chandra (2013) found that the contraction of foreign claims in a European bank was associated with a substantial reduction in domestic credit supply, while the response in Asia was relatively muted.

Against this background, we revisit the bank linkage in the case of the global financial crisis. Our interest in this paper is that the highly integrated banking systems amplify the changes of foreign assets owned by banks before and after the crisis. We

\footnotetext{
Goldberg (2009) explored the recent evolution and consequences of banking globalization. BIS (2010b) documented features of banking globalization developed since the 1980s.
} 
focus on the period from 2006 Q1 to 2009 Q1 as it includes the most current boom and bust episodes, and more recent data do not contain either. Figure 1 shows the foreign assets of banks in expansion and contraction periods.

\section{Figure 1. Foreign assets of banks}

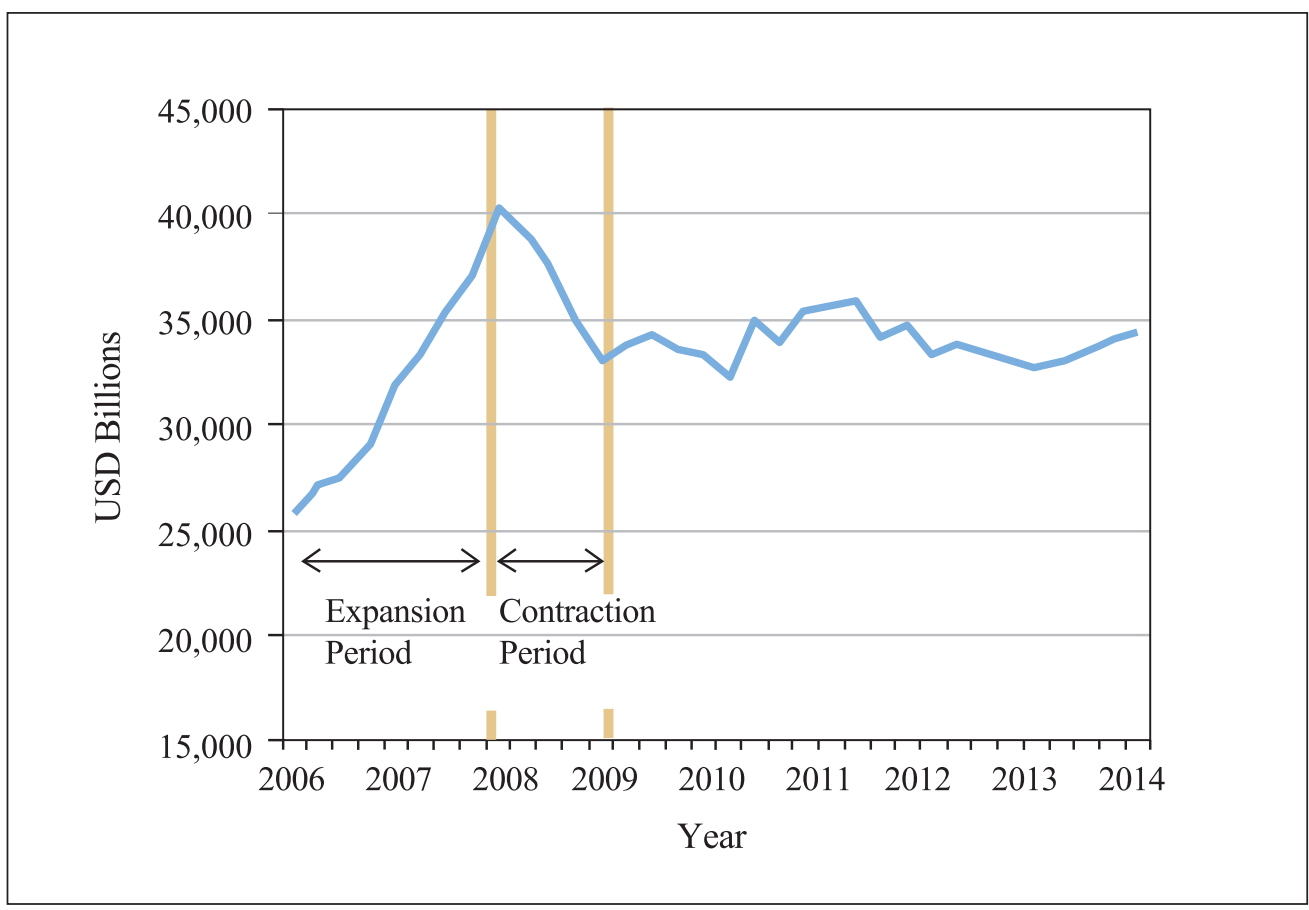

(Note) The data is as of 2014 Q2.

(Source) Bank for International Settlements, Locational Banking Statistics.

Our paper makes contributions to the literature in two ways. First, we analyze the relations between the foreign assets of banks and their lender structure of banking systems using a new specification that accommodates the situation of the global crisis. As the financial shock dramatically affected the banking system across the globe in the crisis, considering only the primary and secondary exposures to the initial shock country is inadequate to capture the effect of bank linkages. We thus use a general form of commonness of lenders and examine how an overall similarity of lending structures generates the vulnerability. By doing so, we apply the idea of common lender channel to the global financial crisis. Second, we examine how these effects are shown differently between the boom and the bust periods and between investing areas. While the past 
studies generally referred only to the reaction in the crisis period, we add a finding to the literature about when and where the bank linkages are much more active in spreading the financial shock across the borders.

\section{Methodology}

\section{A. Econometric Specification and Construction of Variables}

As we focus on the linkages of banking systems, the empirical specification depends on how to quantify the strength of a linkage. ${ }^{2}$ Linkage can be specified with more than one country by definition; thus, we here set an equation for a pair of banking systems. We measure the transaction structure between each pair, and other variables are also defined for pairs. We specify the equation in which the average growth of foreign assets of two banking systems is determined by funding structures that propagate a financial shock across borders. We represent them by the two variables explained below. The advantage of our specification is that we incorporate variables that can capture overall funding structures. Our specification is expressed as follows.

$$
G_{\lambda, \omega}=\text { Constant }+\sum_{i} \beta_{i} \text { Structure }_{i}^{\lambda, \omega}+\eta_{\lambda, \omega} .
$$

Here, $G_{\lambda, \omega}$ is the average growth of external assets of two banking systems, $\lambda$ and $\omega$. Structure $_{i}^{\lambda, \omega}$ denotes the $i$ th variable of funding structure explained below. It is calculated using the data at the starting point of the period so that it captures the structures and characteristics before the boom or the bust begins. $\eta_{\lambda, \omega}$ is the error term.

We set two windows of time and define the period between 2006 Q1 and 2008 Q1 as the time when international banks' assets largely expanded, and the period between 2008 Q2 and 2009 Q1 as the time when they contracted in the adjustment of balance sheets. We define the funding structure variables as follows.

\footnotetext{
2 One distinctive approach to quantify the linkage of international banking systems is the network analysis. Von Peter (2007) and many other studies applied the concepts of network topology in the banking systems and found that the network of cross-border bank exposure had become more tightly connected over time.
} 


\section{Direct transactions of bank flows}

When banking systems in two countries hold a large amount of each other's assets, it is expected that the financial shock is transmitted to each other and their assets consequently expand or contract at a fast pace. If a substantial proportion of country $\lambda$ 's total assets is invested in country $\omega$, an increase in country $\omega$ 's assets will expand the needs for funding from $\lambda$ and it will increase $\lambda$ 's assets. We call this a direct transaction variable and define it as follows.

$$
\text { Direct Transaction }_{\lambda, \omega}=\frac{\mathrm{A}_{\lambda, \omega}+\mathrm{A}_{\omega, \lambda}}{\mathrm{A}_{\lambda}+\mathrm{A}_{\omega}} \text {. }
$$

Here, $A_{\lambda, \omega}$ is assets invested by country $\lambda$ in country $\omega$, and $A_{\lambda}=\sum_{\mathrm{m}=1}^{\mathrm{M}} A_{\lambda, \mathrm{m}}$ is the total foreign assets in all $M$ countries that country $\lambda$ possesses. Since we focus on foreign assets, $A_{\lambda, \lambda}$ is defined as 0 . Figure 2 depicts the outline of the borrower and lender structures for the relevant pair of countries.

Figure 2. Borrower and lender structures

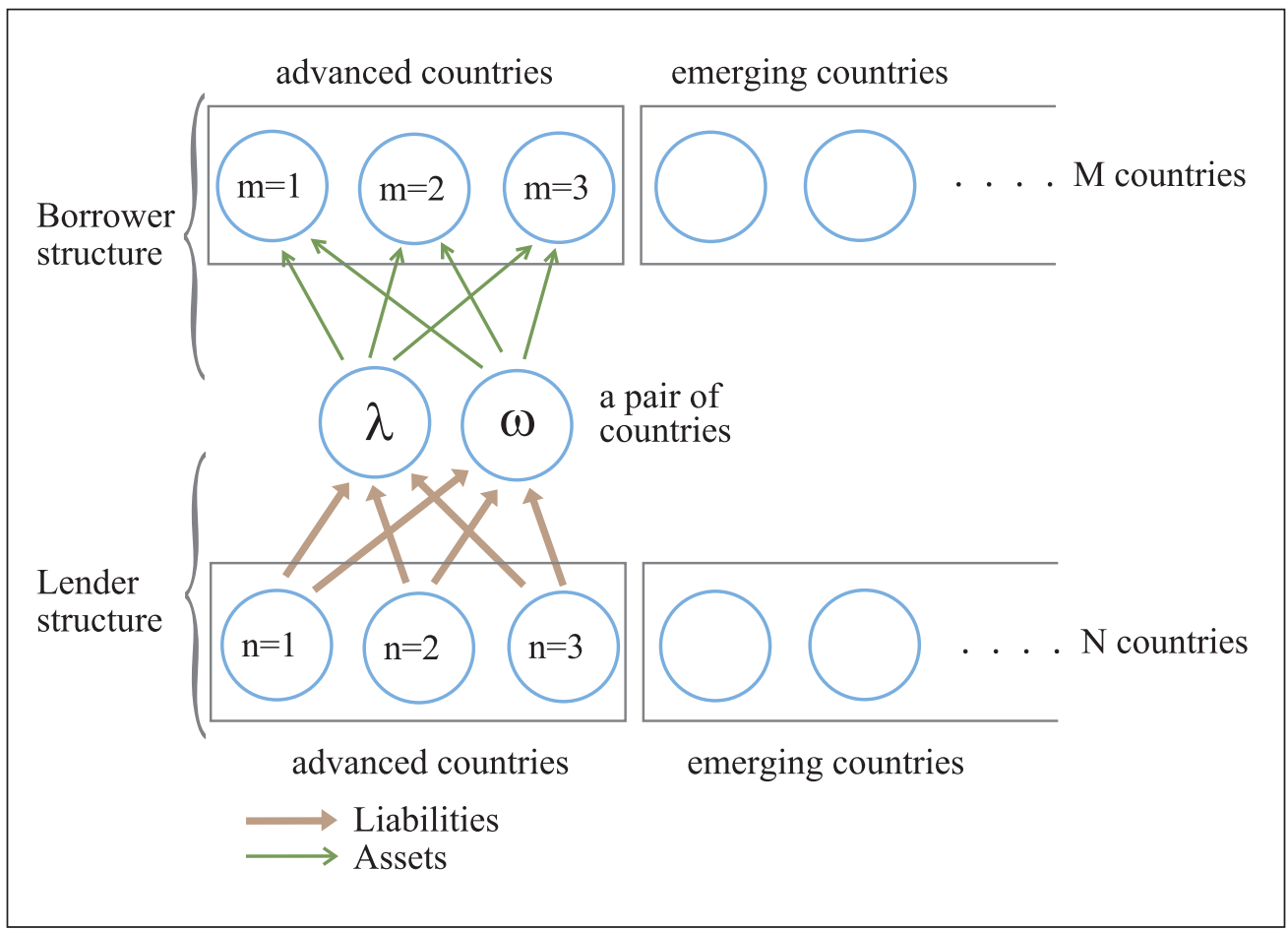




\section{Indirect lender structures}

The indirect lender structures among banking systems also affect the development of the external assets of banks. Van Rijckeghem and Weder (2003) stated that a common lender effect exists if a bank creditor withdraws funds from a country after experiencing an unexpected loss in another country. The underlying mechanism is that the banks withdraw funds simultaneously from various countries in order to restore the capital asset ratios or to lessen the risk exposure. This results in the countries with much reliance on a common lender being forced to shrink their foreign assets accordingly. Here, a common lender is assumed to resort to a sudden withdrawal of funds regardless of profitability in each investing country once in the face of crisis. On the other hand, if the common lender distinguishes the places from which they withdraw funds, considering their risk and return profiles, the common lender effect can be mitigated somewhat. In addition, a similar mechanism can work in the boom if banks invest ample funds abroad with little consideration of asset properties. Comparing the result for the boom and the bust periods allows us to examine the asymmetry of lending behavior between both periods.

We here calculate the index on the similarity of the lender structure following the definition in Geršl (2007) and it is given by:

Similarity of Lender Structure $_{\lambda, \omega}=\sum_{\mathrm{n}=1}^{N_{\lambda, \omega}} \frac{L_{\lambda, n}+L_{\omega, n}}{L_{\lambda}+L_{\omega}}\left[1-\frac{\left|L_{\lambda, n} / L_{\lambda}-L_{\omega, n} / L_{\omega}\right|}{L_{\lambda, n} / L_{\lambda}+L_{\omega, n} / L_{\omega}}\right]$.

In this equation, $L_{k, l}$ is country $k$ 's liabilities from country $l$, and $L_{k}=\sum_{\mathrm{n}=1}^{N_{\lambda, \omega}} L_{k, n}$ is the total liabilities from $N_{\lambda, \omega}$ that denotes all countries excluding countries $\lambda$ and $\omega$. The above index is calculated as a weighted sum. The first term shows the average share of liabilities from a common creditor $(n)$ with respect to the total external liabilities of two countries. The second term reflects the degree of similarities of the shares of external liabilities that two countries gain from the common creditor. The index does not include the information contained in the direct lending between $\lambda$ and $\omega$, so the direct transactions and similarity of the lender structure take complementary roles in grasping the whole lending structure. 


\section{B. Data}

We use the Bank for International Settlements (BIS) International Locational Banking Statistics for variables referring to the external assets and liabilities of banks. The Gross Domestic Product (GDP) data are from the International Monetary Fund (IMF) World Economic Outlook database. In addition, we use the data given in Beck et al. (2000) to capture private domestic credit.

The BIS data cover the external assets and liabilities that banks hold beyond the borders, and the claims are aggregated across all deposit-taking banks in each country where the banks are located. The data can be classified by the location of their counterparties. When we refer to the assets in advanced and emerging countries in this paper, we follow the definition of developed and developing countries given by BIS. ${ }^{3}$

Our dataset is the foreign claims of 22 major economies, ${ }^{4}$ and we compute 231 combinations of country pairs. ${ }^{5}$ Calculating the average growth of assets, we use the data from 2006 Q1 to 2008 Q1 and from 2008 Q2 to 2009 Q1 for periods we define to be expansion and contraction periods, respectively. The structure variables are calculated at the beginning of the period. ${ }^{6}$

\section{Estimation}

We estimate Equation (1) with cross-section data and repeat it for two windows of time defined as the expansion and contraction periods. We carry out ordinary least squares. We can reasonably assume that the endogeneity problem is limited in our specification because our independent variable is calculated as changes in respective periods of time, while dependent variables are evaluated at the starting periods of time. ${ }^{7}$ We provide Huber and White heteroscedasticity-consistent standard errors as heteroscedasticity is expected in the data.

\footnotetext{
${ }^{3}$ The BIS data used in this paper is available on the website. A prominent feature of the BIS data is that datasets are classified both by location of lenders and borrowers in the same period, allowing us to produce the lender structure variables properly and analyze asset and liability positions consistently.

${ }^{4}$ The countries are Australia, Austria, Belgium, Canada, Cyprus, Finland, France, Germany, Greece, Ireland, Italy, Japan, Luxembourg, the Netherlands, Portugal, Spain, Denmark, Norway, Sweden, Switzerland, the United Kingdom, and the United States.

${ }^{5}$ In some empirical tests, we use 210 observations due to the deficiency of the data.

${ }^{6}$ Due to the limited availability of the data, factor variables are based on the annual data in 2006 and 2008.

${ }^{7}$ Upon checking the correlations of each data, we found that the correlation coefficients are below 0.4 in all samples and thus serious correlation does not occur in our dataset.
} 


\section{Results}

We first estimate the effect of direct and indirect linkages for the development of claims. The result presented in Table 1 shows that direct transactions are statistically significant and have a positive effect in the expansion period and a negative effect in the contraction period. This suggests that a tight linkage between two banking systems affects expanding and shrinking assets and consequently escalates the boom and the bust. It is also evident that the similarity of the lender structure is influential with statistical significance only in the contraction period. This is evidence for the generalized common lender effect having existed in the global financial crisis. In the face of crisis, banks' investment decision is greatly affected by the lending structure. Two banking systems with similar lending structures share funding difficulty in common and are likely to shrink their foreign portfolio simultaneously. On the other hand, when they are in the boom, a similar lender structure does not function to boost the boom of external assets. Abundant funds from the same counterparty do not lead to the increase in the assets. These results suggest that the banks' behavior is asymmetric in terms of the reaction to a financial shock.

Next, we separate regressions for assets classified by the investing areas, advanced and emerging countries. The results are shown in Table 2. As for the effect of direct transactions, we observe that the coefficients are all statistically significant, but those in the advanced countries are larger than those in the emerging countries for both periods. This partly reflects the fact that European banks that had expanded the assets in the intra-euro area in the boom greatly unwound their investments once in the face of the crisis. The similarity of the lender structure is significant only for the advanced countries during the contraction period. This means that when banks face funding difficulty, they shrink assets in the advanced countries accordingly, but maintain assets in the emerging countries. While the investment decisions on the emerging countries are more dependent on other factors such as each country's risk and return profile and less responsive to funding conditions, the investment in the advanced countries are directly affected by funding conditions. 


\section{Table 1. Drivers of worldwide external assets}

$$
G_{\lambda, \omega}=\text { Constant }+\sum_{i} \beta_{i} \text { Structure }_{i}^{\lambda, \omega}+\eta_{\lambda, \omega}
$$

\begin{tabular}{|l|c|c|}
\hline $\begin{array}{l}\text { Dependent variable: } \\
\text { Average growth of external assets } \\
\text { of two banking systems }\end{array}$ & Expansion period & Contraction period \\
\hline Independent variables: & $\begin{array}{c}0.57^{* * *} \\
(0.14)\end{array}$ & $\begin{array}{c}-0.56^{* * *} \\
(0.15)\end{array}$ \\
\hline Direct transactions & $\begin{array}{c}3.80 \\
(2.58)\end{array}$ & $\begin{array}{c}-7.88^{* *} \\
(2.82)\end{array}$ \\
\hline Similarity of lender structure & $2.94 * * *-\cdots$ \\
$(0.90)$ & -1.36 \\
\hline Constant & 231 & 231 \\
\hline Number of observations & 0.22 & 0.22 \\
\hline Adjusted $R$-squared & 17.75 & 20.04 \\
\hline$F$-value & $1.02)$ \\
\hline
\end{tabular}

(Note) Standard errors are in parentheses. *** indicates the results are statistically significant at the $1 \%$ level, ** at the $5 \%$ level. 
Table 2. Drivers of external asset by investing areas

$$
G_{\lambda, \omega}=\text { Constant }+\sum_{i} \beta_{i} \text { Structure }_{i}^{\lambda, \omega}+\eta_{\lambda, \omega}
$$

\begin{tabular}{|l|c|c|c|c|}
\hline \multirow{2}{*}{$\begin{array}{l}\text { Dependent variable: } \\
\text { Average growth of external } \\
\text { assets of two banking systems }\end{array}$} & $\begin{array}{c}|c| \\
\text { Edvanced } \\
\text { countries }\end{array}$ & $\begin{array}{c}\text { Emerging } \\
\text { countries }\end{array}$ & $\begin{array}{c}\text { Advanced } \\
\text { countries }\end{array}$ & $\begin{array}{c}\text { Emerging } \\
\text { countries }\end{array}$ \\
\hline Independent variables: & & & & \\
\hline Direct transactions & $\begin{array}{c}0.46^{* * *} \\
(0.11)\end{array}$ & $\begin{array}{c}0.04 * * * \\
(0.01)\end{array}$ & $\begin{array}{c}-0.46^{* * *} \\
(0.13)\end{array}$ & $\begin{array}{c}-0.05^{* * *} \\
(0.02)\end{array}$ \\
\hline Similarity of lender structure & $\begin{array}{c}2.91 \\
(2.05)\end{array}$ & $\begin{array}{c}0.17 \\
(0.19)\end{array}$ & $\begin{array}{c}-6.49 * * \\
(2.41)\end{array}$ & $\begin{array}{c}0.18 \\
(0.27)\end{array}$ \\
\hline Constant & $2.24 * * *$ \\
$(0.72)$ & $0.33 * * *$ & -1.02 & $-0.40 * * *$ \\
$(0.07)$ & $(0.87)$ & $(0.10)$ \\
\hline Number of observations & 231 & 231 & 231 & 231 \\
\hline Adjusted $R$-squared & 0.21 & 0.15 & 0.21 & 0.15 \\
\hline$F$-value & 17.54 & 11.65 & 18.08 & 7.41 \\
\hline
\end{tabular}

(Note) Standard errors are in parentheses. $* * *$ indicates the results are statistically significant at the $1 \%$ level, ** at the $5 \%$ level.

\section{Robustness Check : Country-specific Factors}

We here test the equation incorporating country specific factors to check the robustness of our results. The factors are adopted to control macroeconomic determinants of asset growth in two banking systems, and this is a common practice in the contagion literature. The specification is:

$$
G_{\lambda, \omega}=\text { Constant }+\sum_{i} \beta_{i} \text { Structure }_{i}^{\lambda, \omega}+\sum_{j} \theta_{j} \text { Factor }_{j}^{\lambda, \omega}+\eta_{\lambda, \omega} \cdot
$$

Here, Factor $_{j}^{\lambda, \omega}$ represents the $j$ th variable of country-specific factors, is the average 
of country-specific factors that influence the external asset positions of the pair countries, and is calculated with the data throughout the period. The notations of other terms in Equation (2) are shown in the description for Equation (1).

The country-specific factors we employ are the GDP growth rate, private credit in home country, and net external liability per GDP, following the relevant literature in foreign bank lending. The GDP growth rate and private domestic credit are commonly used in measuring the effect of home country shocks (Goldberg 2005, Buch et al. 2005). We assume that those two variables reflect profitability in domestic investment and that banks aim to maximize their profits in comparing domestic and foreign return. While the GDP growth rate reflects macroeconomic circumstances, private domestic credit captures the environment of banks' domestic investment including not only the domestic return of assets but also banks' stance to additional investment. The net external liability per GDP is assumed to reflect the vulnerability of banking systems with which banks are more likely to face the withdrawal of funds once the crisis occurs. As shown in Table 3, we assure that the linkage variables are still significant and the results are consistent with the above results. 
Table 3. Drivers of external assets worldwide

$$
G_{\lambda, \omega}=\text { Constant }+\sum_{i} \beta_{i} \text { Structure }_{i}^{\lambda, \omega}+\sum_{j} \theta_{j} \text { Factor }_{j}^{\lambda, \omega}+\eta_{\lambda, \omega}
$$

\begin{tabular}{|c|c|c|}
\hline $\begin{array}{l}\text { Dependent variable: } \\
\text { Average growth of external assets } \\
\text { of two banking systems }\end{array}$ & Expansion period & Contraction period \\
\hline \multicolumn{3}{|l|}{ Independent variables: } \\
\hline \multicolumn{3}{|l|}{ Funding structure } \\
\hline Direct transactions & $\begin{array}{c}0.54 * * * \\
(0.14)\end{array}$ & $\begin{array}{c}-0.52 * * * \\
(0.15)\end{array}$ \\
\hline Similarity of lender structure & $\begin{array}{c}2.01 \\
(2.63)\end{array}$ & $\begin{array}{c}-9.87 * * \\
(3.09)\end{array}$ \\
\hline \multicolumn{3}{|l|}{ Country specific factors } \\
\hline GDP growth rate & $\begin{array}{c}-40.07 * * * \\
(13.14)\end{array}$ & $\begin{array}{c}25.23 * * * \\
(9.31)\end{array}$ \\
\hline Private domestic credit & $\begin{array}{l}-6.05 \\
(8.21)\end{array}$ & $\begin{array}{l}10.11^{*} \\
(5.67)\end{array}$ \\
\hline Net external positions & $\begin{array}{l}-0.21 \\
(0.35)\end{array}$ & $\begin{array}{c}0.91 * * \\
(0.36)\end{array}$ \\
\hline Constant & $\begin{array}{c}8.37 * * * \\
(1.31)\end{array}$ & $\begin{array}{c}-3.56 * * * \\
(1.37)\end{array}$ \\
\hline Number of observations & 210 & 210 \\
\hline Adjusted $R$-squared & 0.22 & 0.27 \\
\hline$F$-value & 10.52 & 20.04 \\
\hline
\end{tabular}

(Note) Standard errors are in parentheses. *** indicates the results are statistically significant at the $1 \%$ level, ** at the $5 \%$ level, * at the $10 \%$ level.

Additionally, we attempt to discuss interpretations for the results on country-specific factors. The GDP growth rate and the private domestic factors are negative in the expansion period and positive in the contraction period, while statistical significance is observed partly. As we assume that both reflect the environment of domestic investment following the earlier literature, the negative sign implies a substitution effect in banks' 
asset allocation. The countries with a good investment environment are likely to increase domestic assets while decreasing foreign assets. Looking at the contraction period, in contrast, the result presents a negative sign, implying that countries with good economic environment are likely to maintain the level of foreign asset even in the crisis period. The net external position is significantly positive during the contraction period, contrary to the hypothesis. The result shows that countries with a large net liability did not incur severe contraction of assets but rather continued to grow their assets abroad even in the face of crisis.

The results for investing areas are shown in Table 4. We again confirm that the results for the lending structure variables are maintained and they are mainly due to the change in claims on the advanced countries. The GDP growth rate is negative in the cases for the advanced countries and this is consistent with the finding in Goldberg (2005), which represents the fact that investments in advanced countries are likely to substitute for domestic investment, while those in emerging countries are not. Private domestic credit shows a result similar to that for the GDP growth rate. 
Table 4. Drivers of external assets by investing areas

$$
G_{\lambda, \omega}=\text { Constant }+\sum_{i} \beta_{i} \text { Structure }_{i}^{\lambda, \omega}+\sum_{j} \theta_{j} \text { Factor }_{j}^{\lambda, \omega}+\eta_{\lambda, \omega}
$$

\begin{tabular}{|c|c|c|c|c|}
\hline \multirow{2}{*}{$\begin{array}{l}\text { Dependent variable: } \\
\text { Average growth of external } \\
\text { assets of two banking systems }\end{array}$} & \multicolumn{2}{|c|}{ Expansion period } & \multicolumn{2}{|c|}{ Contraction period } \\
\hline & $\begin{array}{l}\text { Advanced } \\
\text { countries }\end{array}$ & $\begin{array}{l}\text { Emerging } \\
\text { countries }\end{array}$ & $\begin{array}{l}\text { Advanced } \\
\text { countries }\end{array}$ & $\begin{array}{l}\text { Emerging } \\
\text { countries }\end{array}$ \\
\hline \multicolumn{5}{|l|}{ Independent variables: } \\
\hline \multicolumn{5}{|l|}{ Funding structure } \\
\hline Direct transactions & $\begin{array}{c}0.44 * * * \\
(0.11)\end{array}$ & $\begin{array}{c}0.03 * * * \\
(0.01)\end{array}$ & $\begin{array}{c}-0.43^{* * *} \\
(0.12)\end{array}$ & $\begin{array}{c}-0.05 * * * \\
(0.01)\end{array}$ \\
\hline Similarity of lender structure & $\begin{array}{c}1.76 \\
(2.14)\end{array}$ & $\begin{array}{c}0.17 \\
(0.20)\end{array}$ & $\begin{array}{c}-8.16^{* * *} \\
(2.65)\end{array}$ & $\begin{array}{c}0.03 \\
(0.28)\end{array}$ \\
\hline \multicolumn{5}{|l|}{ Country specific factors } \\
\hline GDP growth rate & $\begin{array}{c}-24.71 * * \\
(10.91)\end{array}$ & $\begin{array}{l}-0.85 \\
(1.02)\end{array}$ & $\begin{array}{c}20.33 * * * \\
(7.87)\end{array}$ & $\begin{array}{c}4.18^{* * * *} \\
(0.90)\end{array}$ \\
\hline Private domestic credit & $\begin{array}{l}-3.84 \\
(6.91)\end{array}$ & $\begin{array}{c}-1.92 * * * \\
(0.59)\end{array}$ & $\begin{array}{c}5.18 \\
(5.10)\end{array}$ & $\begin{array}{c}1.50 * * * \\
(0.46)\end{array}$ \\
\hline Net external positions & $\begin{array}{l}-0.09 \\
(0.29)\end{array}$ & $\begin{array}{l}-0.03 \\
(0.03)\end{array}$ & $\begin{array}{l}0.75^{*} \\
(0.31)\end{array}$ & $\begin{array}{c}0.04 \\
(0.03)\end{array}$ \\
\hline Constant & $\begin{array}{c}5.64^{* * *} \\
(1.26)\end{array}$ & $\begin{array}{c}0.58^{* * *} \\
(0.12)\end{array}$ & $\begin{array}{l}-2.48^{*} \\
(1.18)\end{array}$ & $\begin{array}{c}-0.83^{* * *} \\
(0.14)\end{array}$ \\
\hline Number of observations & 210 & 210 & 210 & 210 \\
\hline Adjusted $R$-squared & 0.24 & 0.21 & 0.25 & 0.29 \\
\hline$F$-value & 17.54 & 11.65 & 18.08 & 7.41 \\
\hline
\end{tabular}

(Note) Standard errors are in parentheses. *** indicates the results are statistically significant at the $1 \%$ level, ** at the $5 \%$ level, * at the $10 \%$ level. 


\section{Conclusion}

In this paper we aim to explore whether highly integrated banking systems escalated the boom and the bust of foreign assets owned by banks before and after the global financial crisis. We contribute to the literature by conducting an analysis using a new specification that accommodates the situation in which the shock is spread globally. We then find that direct linkage of banks encourages the boom and the bust of the foreign assets, and the similarity of the banks' lending structure further promotes the contraction of assets in the crisis period. We also examine that shock amplification through bank linkages is shown differently between the boom and the bust periods and between investing areas. We add a finding to the literature about a negative financial shock being likely to be amplified especially in the advanced economies.

Our research offers a policy implication to prevent the amplification of financial crisis. Our findings in the contraction period suggest that banks should hold the funding structure that is unique. This means that global funding or diversification does not necessarily reduce risks once crisis occurs. The prudential policies need to monitor how each banking system is exposed to common architecture of funding sources in order to detect a potential risk. Our evidence for a fragile aspect of integrated banking systems across borders is in line with the discussion of robust-yet-fragile property of the highly interconnected financial networks, which was suggested by Haldane (2009) and recently modeled in formal terms by Acemoglu et al. (2015).

The analysis in this paper focuses on the global location of funding structure, but it is confirmed that the banks' resilience to the shock depends on the composition of funding sources in terms of currencies, sectors, instruments, and maturities (BIS, 2010a). Incorporating these dimensions in the analysis of connected banking systems remains to be studied in the future research.

Received 29 November 2014, Revised 30 December 2015, Accepted 7 January 2016 


\section{References}

Acemoglu, Daron, Asuman Ozdaglar, and Alireza Tahbaz-Salehi. "Systemic Risk and Stability in Financial Networks.” American Economic Review 105 (2) (2015): 564-608.

Aiyar, Shekhar, and Sonali Jain-Chandra. "Asia and Europe are Different?: Credit Response to Global Bank Deleveraging." Journal of Economic Integration 28 (2013): 269-284, Accessed June, 2013. doi: 10.11130/jei.2013.28.2.269.

Bank for International Settlements Committee on the Global Financial System. "Funding Patterns and Liquidity Management of Internationally Active Banks." CGFS Publications 39 (2010a).

Bank for International Settlements Committee on the Global Financial System. "Longterm Issues in International Banking." CGFS Publications 41 (2010b).

Beck, Thorsten, Asli Demirgüç-Kunt, and Ross Levine. "A New Database on Financial Development and Structure.” World Bank Economic Review 14 (2000): 597-605.

Buch, Claudia M. "Why Do Banks Go Abroad? Evidence from German Data." Journal of Financial Markets, Instruments and Institutions 9 (1) (2000): 33-67.

Buch, Claudia M., Kai Carstensen, and Andrea Schertler. "Macroeconomic Shocks and Foreign Bank Assets." Journal of Money, Credit and Banking 42 (1) (2005): 171-188.

Cetorelli, Nicola, and Linda S. Goldberg. "Global Banks and International Shock Transmission: Evidence from the Crisis.” IMF Economic Review 59 (1) (2011): 41-76.

De Haas, Ralph, and Iman van Lelyveld. "Internal Capital Markets and Lending by Multinational Bank Subsidiaries.” Journal of Financial Intermediation 19 (1) (2009): $1-25$.

Geršl, Adam. "Foreign Banks, Foreign Lending and Cross-Border Contagion: Evidence from the BIS Data.” Czech Journal of Economics and Finance 57 (2007): 27-40.

Goldberg, Linda S. "When is U.S. Bank Lending to Emerging Markets Volatile?" in Preventing Currency Crises in Emerging Markets, ed. Edwards, Sebastian, and Jeffrey A. Frankel. (Chicago: University of Chicago Press, 2002).

Goldberg, Linda S. "The International Exposure of US Banks.” NBER Working Paper 11365 (2005). 
Goldberg, Linda S. "Understanding Banking Sector Globalization.” International Monetary Fund Staff Papers 56 (2009): 171-197.

Haldane, Andrew G. "Rethinking the Financial Network." Speech delivered at the Financial Student Association in Amsterdam (2009).

International Monetary Fund, World Economic Outlook April 2009 (2009).

Kaminsky, Graciela L., and Carmen M. Reinhart. "On Crises, Contagion, and Confusion.” Journal of International Economics 51 (2000): 145-168.

Peek, Joe, and Eric S. Rosengren. "The International Transmission of Financial Shocks: The Case of Japan.” American Economic Review 87 (4) (1997): 495-505.

Van Rijckeghem, Caroline, and Beatrice Weder. "Spillovers through Banking Centers: A Panel Data Analysis of Bank Flows." Journal of International Money and Finance 22 (2003): 483-509.

Von Peter, Goetz. "International Banking Centres: A Network Perspective." BIS Quarterly Review December 2007 (2007): 33-45. 